\title{
Cloning, Sequencing and Characterization of the 'Desulfurization Gene Cluster' From an Isolated Strain Gordonia sp. IITR100
}

\author{
Ashok Kumar Chauhan \\ Environmental Biotechnology Division, \\ Indian Institute of Toxicology Research (Council of Scientific \& Industrial Research) \\ M.G. Marg, Lucknow 226001, India \\ E-mail: ashokchauhan44@gmail.com
}

\author{
Surya Pratap Singh \\ Department of Biochemistry, Faculty of Science \\ Banaras Hindu University, Varanasi
}

Tel: 91-542-670-1543Ｅ-mail: ssingh35@bhu.ac.in

\begin{abstract}
Ashwani Kumar (Corresponding author)
Environmental Biotechnology Division, Indian Institute of Toxicology Research (Council of Scientific \& Industrial Research)

M.G. Marg, Lucknow 226001, India
\end{abstract}

Tel: 91-522-261-2762Ｅ-mail: ashwani.iitr26@gmail.com

Received: March 1, 2014 Accepted: July 20, 2014 Published: July 25, 2014

Doi: 10.5296/jab.v2i2.6027 URL: http://dx.doi.org/10.5296/jab.v2i2.6027

\begin{abstract}
Biodesulfurization of organosulfur compounds is mediated by activity of the enzymes DszA, DszB and DszC. Here, we report the nucleotide sequence of an $11.5 \mathrm{~kb}$ region, containing the $d s z A B C$ genes along with $3.3 \mathrm{~kb}$ upstream and $4.5 \mathrm{~kb}$ down-stream region, from a desulfurizing strain Gordonia sp IITR100. The genes are organized together as $d s z A B C$ in an
\end{abstract}




\section{Macrothink

operon, and their nucleotide sequence is $>99 \%$ identical to those from the Gordonia strains IB, RIPI90A \& CYKS2. The sequence upstream to $d s z A$, is identical to the reported -1 to $-1800 \mathrm{bp}$ from the corresponding region of CYKS2, but presence of two transposase genes was identified in the remaining $2.7 \mathrm{~kb}$ region. Sequence of the region downstream to dszC was found to be distinct from all the desulfurizing organisms. BLAST analysis suggested that the cloned $11.5 \mathrm{~kb}$ region was possibly formed by crossover between the genomes a Mycobacterium and a Gordonia strain at a site $206 \mathrm{bp}$ downstream to $d s z C$. The results have bearing on understanding the organization and horizontal transfer of the desulfurization genes.

Keywords: Biodesulfurization, $d s z A B C$, Gordonia sp. IITR100, Nucleotide sequence 


\section{Introduction}

Several organisms that mediate desulfurization of the organo-sulfur compounds have been characterized. Many of these have also been shown to be effective in biodesulfurization of the various crude oil fractions (Grossman et al., 2001; Furuya et al., 2003; Yu et al., 2006). The desulfurization activity is mediated by a ' $4 \mathrm{~S}$ ' pathway, where the sulfur from target molecule is removed by serial activity of the enzymes DszC, DszA and DszB. In addition, the pathway also requires activity of a NADH-FMN oxidoreductase DszD that allows regeneration of $\mathrm{FMNH}_{2}$ co-factor, needed for the reactions catalyzed by DszC and DszA (Gallagher, 1993; Oldfield et al., 1997). Genes for DszA, -B and -C have been studied from many organisms. Broadly, these are organized together as an operon and are coordinately regulated (Denome et al., 1994; Mohebali \& Ball, 2008).

Based on their organization and nucleotide sequence, dsz genes from different organisms can be categorized in six groups i.e. $d s z A B C$-type1- $d s z A B C$-type6 (Table 1). The dszABC-type1 was described initially from Rhodococus sp. IGTS8 (Denome et al., 1994), and was later found to be present in several other organisms. Here the length of $d s z A, d s z B$ and $d s z C$ is 1362, 1098 and $1254 \mathrm{bp}$, respectively, and an overlap of 4 bp between 3' end of $d s z A$ and 5' end of $d s z B$, but a space of 13 bp between the genes $d s z B$ and $d s z C$ is also present (Table 1). The $d s z A B C$-type 2 has been identified from several strains including Gordonia alkanivorans 1B (Alves et al., 2007). It is $\sim 90 \%$ identical with $d s z A B C$-typel. Here, the length of $d s z A$, $d s z B$, and $d s z C$ is 1425,1098 and $1251 \mathrm{bp}$, respectively. The overlap between $d s z A$ and $d s z B$, and space between $d s z B$ and $d s z C$, is 67 and $10 \mathrm{bp}$, respectively. The $d s z A B C$-type 3 and dszABC-type 4 have been described from thermophilic the bacteria Paenibacillus sp. A11-2 (Ishi et al., 2000) and Bacillus subtilis WU-S2B (Kirimura et al., 2004), respectively, and exhibit 62 and $50 \% \%$ identity with $d s z A B C$-type 1 . Likewise, the $d s z A B C$-type 5 and dszABC-type6 have been characterized from the strains Mycobacterium sp. G3 (Nomura et al 2005) and Gordonia amicalis F.5.25.8 (Kilbane \& Robbins, 2007), and are $\sim 70$ and 84\% identical to $d s z A B C$-type1, respectively. 
Table 1. Details of the various reported $d s z A B C$ operons

\begin{tabular}{|c|c|c|c|c|c|c|c|c|}
\hline $\begin{array}{l}\text { Gene } \\
\text { family }\end{array}$ & Organism & $\begin{array}{l}\text { Accession } \\
\text { No. }\end{array}$ & $\begin{array}{l}d s z A \\
\text { (bp) }\end{array}$ & $\begin{array}{l}\text { Overlap } \\
d s z A / B\end{array}$ & $\begin{array}{l}d s z B \\
(\mathrm{bp})\end{array}$ & $\begin{array}{l}\text { Space/ } \\
\text { overlap } \\
d s z B / C\end{array}$ & $\begin{array}{l}d s z C \\
\text { (bp) }\end{array}$ & $\begin{array}{l}\% \text { identity } \\
\text { with } \\
\text { dsz-typel }\end{array}$ \\
\hline -type1 & $\begin{array}{l}\text { Rhodococcus } \\
\text { erythropolis } \\
\text { IGTS8 }\end{array}$ & U08850.1 & 1362 & 4 & 1098 & $\begin{array}{l}10 \\
\text { (space) }\end{array}$ & 1254 & 100 \\
\hline -type2 & $\begin{array}{l}\text { Gordonia } \\
\text { alkanivorans 1B }\end{array}$ & AY678116.1 & 1425 & 67 & 1098 & $\begin{array}{l}10 \\
\text { (space) }\end{array}$ & 1251 & $\sim 90$ \\
\hline -type3 & $\begin{array}{l}\text { Paenibacillus } \\
\text { sp. A11-2 }\end{array}$ & AB033997.2 & 1365 & 4 & 1062 & $\begin{array}{l}15 \\
\text { (space) }\end{array}$ & 1245 & $\sim 55$ \\
\hline -type4 & $\begin{array}{l}\text { B. subtilus } \\
\text { WU-S2B }\end{array}$ & $\mathrm{AB} 076745.1$ & 1362 & 4 & 1071 & $\begin{array}{l}4 \\
\text { (overlap) }\end{array}$ & 1248 & $\sim 71$ \\
\hline -type5 & $\begin{array}{l}\text { Mycobacterium } \\
\text { sp. G3 }\end{array}$ & AB070603.1 & 1371 & 1 & 1071 & $\begin{array}{l}4 \\
\text { (overlap) }\end{array}$ & 1248 & $\sim 70$ \\
\hline
\end{tabular}

Sequence of the regions, present upstream and downstream to $d s z A B C$-typel, has also been determined. Thus, sequence of a $9.7 \mathrm{~kb}$ DNA from Rhodococus sp. IGTS8, containing $D s z A B C$ genes along with 1544 bp upstream and 4498 bp downstream region, has been described (Denome et al., 1994). Presence of a Rhodococcus promoter and at least three $d s z$ regulatory regions were identified ( $\mathrm{Li}$ et al., 1996) in the 1-385 bp regions, upstream to $d s z A$. In the region downstream to $d s z C$, presence of two sequences that were similar to the insertion sequence IS6120 orfB and IS1166 orfA, respectively, was observed. Similarly, in the 1-1800 bp region, upstream to $d s z A$ from the desulfurizing strain Gordonia sp. CYKS2, sequences similar to insertion elements IS1533 OrfA and IS1534 istB (AY396519.1) were present. In the strain RIPI90A, whose sequence in the upstream region is identical to that from CYKS2, a $d s z$ promoter was identified in the region $50-156 \mathrm{bp}$, upstream to the $d s z A$ (Shavandi et al., 2010). The sequence showed only $52.5 \%$ identity to the promoter sequence of $R$. erythropolis IGTS8.

We have earlier reported the characterization of a bacterium Gordonia sp. IITR 100 that mediates the desulfurization of both thiophenic and non-thiophenic organosulfur compounds (Ahmad et al., 2014). In the present study, nucleotide sequence of an 11554 bp DNA, which includes the genes $d s z A, d s z B$ and $d s z C$, along with 3357 bp upstream and 4481 bp down-stream region, was determined and analyzed. 


\section{Materials and Methods}

The bacterium Gordonia sp. IITR100 was grown in medium-1( $\mathrm{Na}_{2} \mathrm{HPO}_{4}, 2.0 \mathrm{~g} ; \mathrm{KH}_{2} \mathrm{PO}_{4}, 1 \mathrm{~g}$; $\mathrm{MgCl}_{2} .6 \mathrm{H}_{2} \mathrm{O}, 0.4 \mathrm{~g} ; \mathrm{NH}_{4} \mathrm{Cl}, 0.4 \mathrm{~g} ; \mathrm{Al}(\mathrm{OH})_{3}, 0.1 \mathrm{~g} ; \mathrm{SnCl}_{2} .2 \mathrm{H}_{2} \mathrm{O}, 0.5 \mathrm{~g} ; \mathrm{KI}, 0.05 \mathrm{~g} ; \mathrm{LiCl}, 0.01$ g; $\mathrm{MnCl}_{2} .4 \mathrm{H}_{2} \mathrm{O}, 0.8 \mathrm{~g} ; \mathrm{H}_{3} \mathrm{BO}_{3}, 0.05 \mathrm{~g} ; \mathrm{ZnCl}_{2}, 0.1 \mathrm{~g} ; \mathrm{CoCl}_{2} \cdot 6 \mathrm{H}_{2} \mathrm{O}, 0.1 \mathrm{~g} ; \mathrm{NiCl}_{2} \cdot 6 \mathrm{H}_{2} \mathrm{O}, 0.1 \mathrm{~g}$; $\mathrm{BaCl}_{2}, 0.05 \mathrm{~g}$; $\left(\mathrm{NH}_{4}\right)_{6} \mathrm{Mo}_{7} \mathrm{O}_{24} .4 \mathrm{H}_{2} \mathrm{O}, 0.05 \mathrm{~g}$, per liter) that contained $17.1 \mathrm{~g}$ sucrose and $50 \mathrm{mg}$ dibenzothiophene (DBT) as carbon and sulfur source, respectively. All the DNA based procedures were done by the standard methods, as described earlier (Macwan et al., 2012).

Table 2. Primers used in the study

\begin{tabular}{lll}
\hline Primers & Primer sequence & Primer details \\
\hline F1 & $\begin{array}{l}\text { GGAATTCCATATGGCTCAACGGCGACA } \\
\text { ACTGCATCTGGCCGGTTTC }\end{array}$ & $\begin{array}{l}\text { Contains 1-36 bases of 5'end of dszA } \\
\text { and site for NdeI (underlined) }\end{array}$ \\
F2 & $\begin{array}{l}\text { GGAATTCCATATGACTCTGTCCGTTGA } \\
\text { AAAGCAGCACGTTCG }\end{array}$ & $\begin{array}{l}\text { Contains 1-32 bases of 5'end of dszC } \\
\text { and site for NdeI }\end{array}$ \\
R1 & $\begin{array}{l}\text { CCGCTCGAGTCAGTGTGTCGAGGATG } \\
\text { CCGGTATCAAGTTCTG }\end{array}$ & $\begin{array}{l}\text { Contains 1-33 bases of 3'end of dszA } \\
\text { and site for XhoI }\end{array}$ \\
R2 & CCGCCCAAGCTTCTAGGAGGTGAAGC & $\begin{array}{l}\text { Contains 1-27 bases of 3'end of dszC } \\
\text { and site for HindIII }\end{array}$ \\
\hline
\end{tabular}

Briefly, the genomic DNA was isolated by phenol: chloroform extraction, and genes $d s z A$ and $d s z C$ were amplified by using primer sets F1-R1 (Table 2) and F2-R2, respectively. These were cloned in E.coli DH5 $\alpha$ cells, after their ligation with the pGEM-T Easy (Promega Madison, USA) vector. Insert DNA were cut from the plasmids by restriction digestion, labeled with DIG-DNA Labeling Kit (Roche, Mannheim, Germany), and used as probes for Southern hybridization. In EcoR1- digested IITR100 total DNA, presence of two fragments $(4.6 \& 2.1 \mathrm{k})$ and other two fragments $(4.8 \& 2.1 \mathrm{~kb})$ was observed, after Southern analysis by using $D s z A$ and $d s z C$ probes, respectively (data not shown). DNA from the gel pieces that contained these fragments was eluted and cloned in DH5 $\alpha$ cells. The transformants, carrying the $d s z$ cross reactive fragments, were selected for sequencing. Briefly, the insert DNA from these clones was limit digested with Sau3A1. Fragments ( $\sim 00 \mathrm{bp})$ were ligated with the BamH1 treated pGEM-T Easy vector, and cloned in DH5 $\alpha$ cells. Nucleotide sequencing was done by using universal M13 primers (Macwan et al., 2012). Likewise, nucleotide sequence of a $3.7 \mathrm{~kb}$ PCR fragment that was obtained by using primers F1\&R2 was also determined. The obtained 11554 bp sequence has been deposited under accession number GenBank KC693733.1 


\section{Results and Discussion}

Nucleotide sequences of large subsets of the genomic DNA from an organism have been extremely useful in providing information about the structure, organization and regulation of the genes (Denome et al., 1994; Li et al., 1996). These have also been useful in understanding the past events that might have occurred during their acquisition, assembly, evolution, and transfer amongst different organisms (Yano et al., 2010). Results of this study revealed the sequence of an $11.5 \mathrm{~kb}$ region of a strain IITR100. It contains $d s z A B C$ genes along with the $3357 \mathrm{bp}$ upstream and 4483 bp down-stream region. Southern hybridization of the EcoR1 digest of the total IITR100 DNA, by using the dszA probe, revealed the presence of two cross reactive fragments. One, the $4593 \mathrm{bp}$ fragment that contained $1236 \mathrm{bp}$ of $d s z A \& 3357 \mathrm{bp}$ upstream to it, and other the $2136 \mathrm{bp}$ fragment that contained part of $d s z A$, all of $d s z B$ and part of $d s z C$ (Figure 1). Similarly, of the two $d s z C$-cross reactive fragments, the $4825 \mathrm{bp}$ fragment contained $344 \mathrm{bp}$ of $d s z C$ and $4481 \mathrm{bp}$ downstream to it, and the $2136 \mathrm{bp}$ fragment was same, which showed hybridization with $d s z A$ probe also. Thus, the size of the genes $d s z A, d s z B$ and $d s z C$ were 1425,1098 and $1251 \mathrm{bp}$, respectively, and these were present together in the order $d s z A B C$ as an operon (Figure 1). Moreover, an overlap of 64 bp between $d s z A \& d s z B$ and a gap of $11 \mathrm{bp}$ between $d s z B$ and $d s z C$, was also observed. The sequence was $>99 \%$ identical to $d s z A B C$-type 2 genes (Table 1), reported earlier from the Gordonia strains 1B (AY678116.1), RIPI90 (EU364831.1), and CYKS2 (AY396519.1). The result suggests that this gene is spread widely in different parts of the the world, as shown earlier for $d s z A B C$-typel (Denis-Larose et al., 1997).

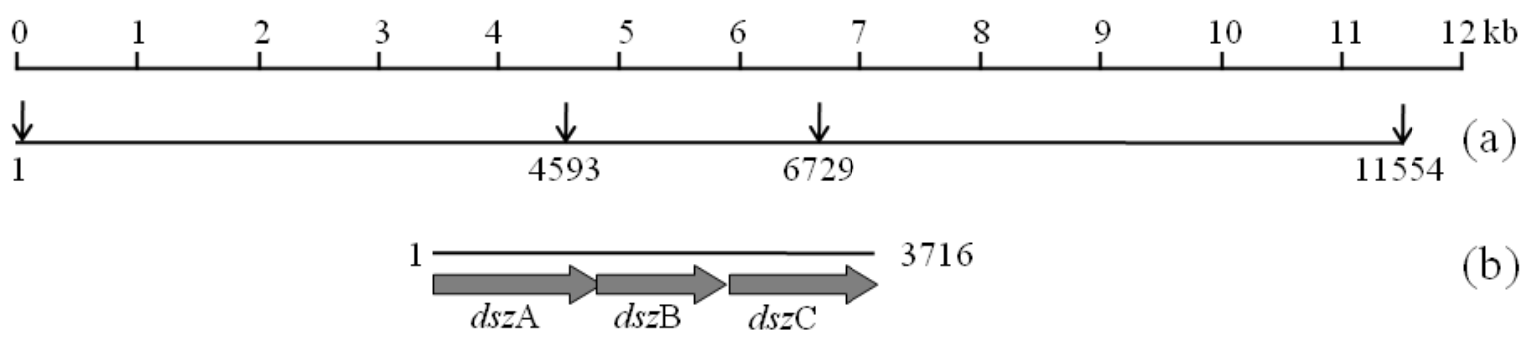

Figure 1. Sequenced DNA fragments; (a) EcoRI fragments that showed hybridization with $d s z$ probes and (b) PCR product. Nucleotides number 1 and 3716 of the PCR product correspond to 3357 and 7073 of the 11554 bp sequence

In IITR100, sequence up to $-362,-380 \&-1800 \mathrm{bp}$ in the region upstream to $d s z A$, was identical to the reported sequences of the corresponding regions from the strains RIPI90, $1 \mathrm{~B}$ and CYKS2, respectively. Further analysis of the upstream region identified the presence of three transposase genes at the sites 1-967 bp, 1047-2291 bp and 2334-3094 bp that were $>80 \%$ identical to Transposase IS1533 (AFJ34716.1), Transposase IS1533 (AET20231.1) and Transposase IS1xx1 (CAM01140.1), respectively. Similarly, in the region downstream to $d s z C$, the sequence of 204, 204 and 139 bp region was identical to the corresponding regions 
of the strains RIPI90, 1B and CYKS2, respectively, but was distinct in the remaining region (Figure 2). Furthermore, presence of a cytosine permease (ABL93443.1) and a short-chain dehydrogenase/reductase (ACY19419.1) was identified at the sites 7985-9424 bp and 10529-11326 bp, respectively. While the presence of transposaes in the upstream region suggests that the $d s z$ genes might have been imported in the past by their horizontal transfer from some other organism (Ochman et al., 2000), role of genes for permease and dehydrogenase enzymes in the downstream region is not clear at present.

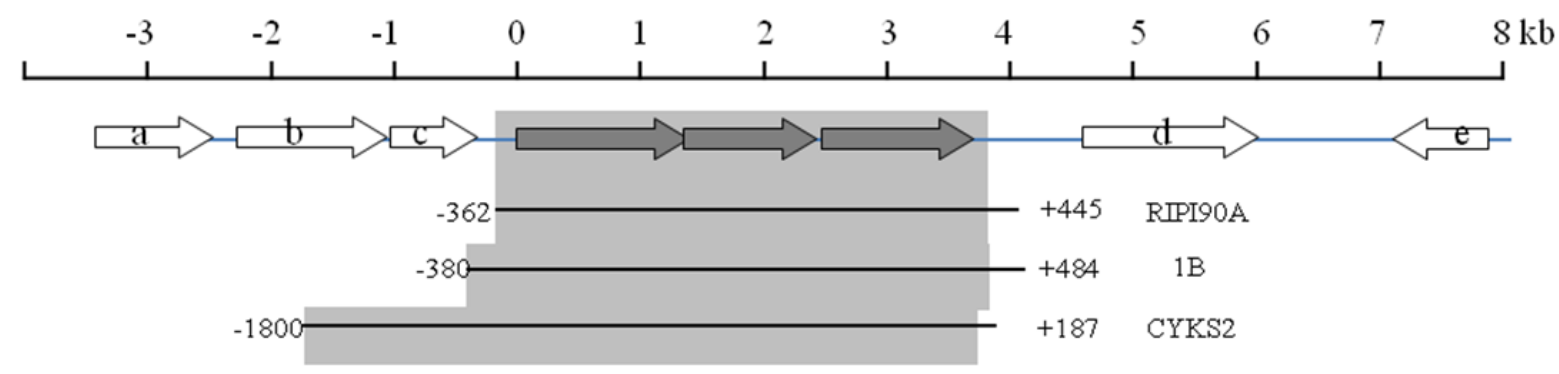

Figure 2. Characterization of the sequenced $11.5 \mathrm{~kb}$ region, and its identity with known $d s z$ genes. Broad arrows indicate the genes identified (a) Transposase IS1533 (AFJ34716.1), (b)

Transposase IS1533 (AET20231.1), (c) Transposase IS1xx1 (CAM01140.1) (d) cytosine permease (ABL93443.1) and (e) short-chain dehydrogenase/reductase (ACY19419.1). Shaded regions denote sequences that are $>99 \%$ identical to RIPI 90A (EU364831.1), IB (AY678116.1) and CYKS2 (AY396519.1)

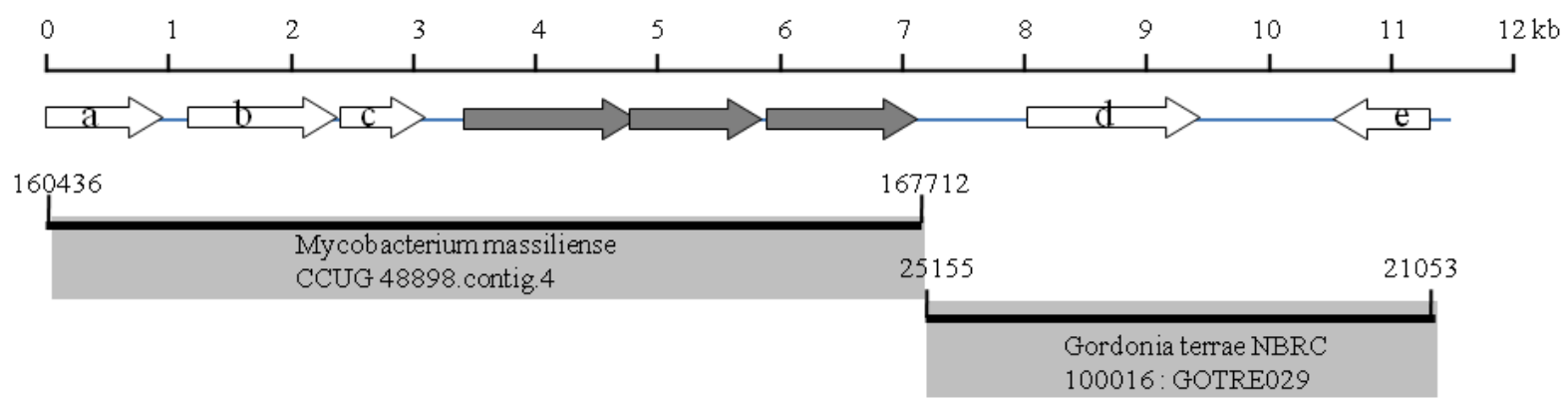

Figure 3. Identity of the sequenced 11.5kb DNA with regions from Mycobacterium massiliense and Gordonia terrae (shaded region)

BLAST analysis of the sequenced $11.5 \mathrm{~kb}$ IITR100 DNA revealed (Fig 3) that its region 1-7277 was $99 \%$ identical to the $160436-167712$ bp region of the whole genome of Mycobacterium massiliense CCUG 48898 (AKVF01000005), and the 7278-11379 bp region was $99 \%$ identical to $25155-21053$ bp region of the Gordonia terrae NBRC 100016 (BAFD01000029.1). It suggests that this region in IITR100 was possibly generated by a cross-over between the two genomes. Presence of clustered $d s z A B C$ genes, under the control of 
a promoter that has been identified in various Gordonia strains, suggest that IITR100 is a robust bacterium for the desulfurization of sulfur compounds.

\section{Acknowledgements}

AKC sincerely thanks Indian council of Medical Research, New Delhi, India. Financial assistance by a grant SIP-08 from CSIR, India, is gratefully acknowledged. The funding sources had no role in the study design, and in collection, analysis and interpretation of the data.

\section{References}

Ahmad, A., Chauhan, A. K., Kushwaha, H. N., Javed, S., \& Kumar, A. Preferential desulfurization of dibenzyl sulfide by an isolated Gordonia sp. IITR100. 3Biotech, 1-7. http://dx.doi.org/10.1007/s13205-014-0221-1

Alves, L., Melo, M., Mendonca, D., Simoes, F., Matos, J., Tenreiro, R., \& Girio, F. M. (2007). Sequencing, cloning and expression of the $d s z$ genes required for dibenzothiophene sulfone desulfurization from Gordonia alkanivorans strain 1B. Enzyme and Microbial Technology, 40(6), 1598-1603. http://dx.doi.org/10.1016/j.enzmictec.2006.11.008

Denis-Larose, C., Labbé, D., Bergeron, H., Jones, A. M., Greer, C. W., al-Hawari, J., Grossman, M. J., Sankey, B. M., \& Lau, P. C. (1997). Conservation of plasmid-encoded dibenzothiophene desulfurization genes in several rhodococci. Applied and environmental microbiology, 63(7), 2915-2919.

Denome, S. A., Oldfield, C., Nash, L. J., \& Young, K. D. (1994). Characterization of the desulfurization genes from Rhodococcus sp. strain IGTS8. Journal of bacteriology, 176(21), 6707-6716.

Furuya, T., Ishii, Y., Noda, K., Kino, K., \& Kirimura, K. (2003). Thermophilic biodesulfurization of hydrodesulfurized light gas oils by Mycobacterium phlei WU-F1. FEMS Microbiol Lett, 221(1), 137-142. http://dx.doi.org/ 10.1016/S0378-1097(03)00169-1

Gallagher, J. R., Olson, E. S., \& Stanley, D. C. (1993). Microbial desulfurization of dibenzothiophene: a sulfur-specific pathway. FEMS Microbiol Lett, 107(1), 31-35. http://dx.doi.org/10.1111/j.1574-6968.1993.tb05999.x

Grossman, M. J., Lee, M. K., Prince, R. C., Minak-Bernero, V., George, G. N., \& Pickering, I. J. (2001). Deep desulfurization of extensively hydrodesulfurized middle distillate oil by Rhodococcus sp. strain ECRD-1. Appl Environ Microbiol, 67(4), 1949-1952. http://dx.doi.org/10.1128/AEM.67.4.1949-1952.2001

Ishii, Y., Konishi, J., Okada, H., Hirasawa, K., Onaka, T., \& Suzuki, M. (2000). Operon Structure and Functional Analysis of the Genes Encoding Thermophilic Desulfurizing Enzymes of Paenibacillus sp. A11-2. Biochemical and biophysical research communications, 270(1), 81-88. http://dx.doi.org/10.1006/bbrc.2000.2370

Kilbane II, J. J., \& Robbins, J. (2007). Characterization of the dszABC genes of Gordonia 
amicalis F. 5.25. 8 and identification of conserved protein and DNA sequences. Applied $\begin{array}{llll}\text { microbiology and } & \text { biotechnology, }\end{array}$ http://dx.doi.org/10.1007/s00253-007-0895-y

Kirimura, K., Harada, K., Iwasawa, H., Tanaka, T., Iwasaki, Y., Furuya, T., ... Kino, K. (2004). Identification and functional analysis of the genes encoding dibenzothiophene-desulfurizing enzymes from thermophilic bacteria. Applied microbiology and biotechnology, 65(6), 703-713. http://dx.doi.org/10.1007/s00253-004-1652-0

Li, M. Z., Squires, C. H., Monticello, D. J., \& Childs, J. D. (1996). Genetic analysis of the dsz promoter and associated regulatory regions of Rhodococcus erythropolis IGTS8. Journal of bacteriology, 178(22), 6409-6418.

Macwan, A. S., Kukshal, V., Srivastava, N., Javed, S., Kumar, A., \& Ramachandran, R. (2012). Crystal Structure of the Hexachlorocyclohexane Dehydrochlorinase (LinA-Type2): Mutational Analysis, Thermostability and Enantioselectivity. PloS one, 7(11), e50373. http://dx.doi.org/10.1371/journal.pone.0050373

Mohebali, G., \& Ball, A. S. (2008). Biocatalytic desulfurization (BDS) of petrodiesel fuels. Microbiology, 154(8), 2169-2183. http://dx.doi.org/10.1099/mic.0.2008/017608-0

Nomura, N., Takada, M., Okada, H., Shinohara, Y., Nakajima-Kambe, T., Nakahara, T., \& Uchiyama, H. (2005). Identification and functional analysis of genes required for desulfurization of alkyl dibenzothiophenes of Mycobacterium sp. G3. Journal of bioscience and bioengineering, 100(4), 398-402. http://dx.doi.org/10.1263/jbb.100.398

Ochman, H., Lawrence, J. G., \& Groisman, E. A. (2000). Lateral gene transfer and the nature of bacterial innovation. Nature, 405(6784), 299-304. http://dx.doi.org/10.1038/35012500

Oldfield, C., Pogrebinsky, O., Simmonds, J., Olson, E. S., \& Kulpa, C. F. (1997). Elucidation of the metabolic pathway for dibenzothiophene desulphurization by Rhodococcus sp. strain IGTS8 (ATCC 53968). Microbiology, 143(9), 2961-2973. http://dx.doi.org/10.1099/00221287-143-9-2961

Shavandi, M., Sadeghizadeh, M., Khajeh, K., Mohebali, G., \& Zomorodipour, A. (2010). Genomic structure and promoter analysis of the $d s z$ operon for dibenzothiophene biodesulfurization from Gordonia alkanivorans RIPI90A. Applied microbiology and biotechnology, 87(4), 1455-1461. http://dx.doi.org/10.1007/s00253-010-2605-4

Yano, H., Miyakoshi, M., Ohshima, K., Tabata, M., Nagata, Y., Hattori, M., \& Tsuda, M. (2010). Complete nucleotide sequence of TOL plasmid pDK1 provides evidence for evolutionary history of IncP-7 catabolic plasmids. Journal of bacteriology, 192(17), 4337-4347. http://dx.doi.org/10.1128/JB.00359-10

Yu, B., Xu, P., Shi, Q., \& Ma, C. (2006). Deep desulfurization of diesel oil and crude oils by a newly isolated Rhodococcus erythropolis strain. Applied and environmental microbiology, 72(1), 54-58. http://dx.doi.org/10.1128/AEM.72.1.54-58.2006 


\section{Copyright Disclaimer}

Copyright reserved by the author(s).

This article is an open-access article distributed under the terms and conditions of the Creative Commons Attribution license (http://creativecommons.org/licenses/by/3.0/). 